\title{
Point-of-care ultrasound detection of tracheal edema caused by smoke inhalation
}

\author{
T Kameda*, M Fujita \\ From 9th WINFOCUS World Congress on Ultrasound in Emergency and Critical Care \\ Hong Kong. 6-9 November 2013
}

\section{Background}

Smoke inhalation is the leading cause of death due to fires. When a patient presents with smoke inhalation, prompt assessment of the airway and breathing is necessary. Point-of-care ultrasound is used for the rapid assessment of critically-ill or injured patients. To the best of our knowledge, the use of point-of-care ultrasound for the detection of tracheal edema caused by smoke inhalation has never been reported in the English literature.

\section{Case presentation}

A 54-year-old male was transferred to the emergency department with an increasingly evident cough, carbonaceous sputa and rhinorrhea about six hours after inhaling smoke caused by a fire in his locked bedroom. On examination, he was alert. His oxygen saturation was $94 \%$ on 2 liters of oxygen by nasal cannula, with a respiratory rate of 25 breaths/min, and his heart rate was 106 beats $/ \mathrm{min}$, his blood pressure was $151 / 100 \mathrm{mmHg}$ and his body temperature was $37.3^{\circ} \mathrm{C}$. He had no surface burns on the face and no edema or erosion in the oral cavity. He had hoarseness without stridor. His breath sounds were positive for expiratory wheezes. Chest X-rays indicated narrowing of the trachea. Laryngoscopy showed light edema and erosive findings on the supraglottic region. Bedside point-of-care ultrasound revealed hypoechoic thickening of the tracheal wall, which was consistent with tracheal edema. The thickening was confirmed by a computed tomographic scan. The patient was carefully monitored with preparation for emergency airway management and was treated with supplemental oxygen, an aerosolized $\beta 2$ adrenergic agonist and a single intravenous administration of methylprednisolone. The symptoms were subsequently relieved, and reexamination by ultrasound after two days showed remission of the wall thickening.

Department of Emergency Medicine, Red Cross Society Azumino Hospital, Azumino, Japan

SpringerOpen $^{\odot}$

C 2014 Kameda and Fujita; licensee Spinger. This is an Open Access article distributed under the terms of the Creative Commons Attribution License (http://creativecommons.org/licenses/by/2.0), which permits unrestricted use, distribution, and reproduction in any medium, provided the original work is properly cited. The Creative Commons Public Domain Dedication waiver (http:// creativecommons.org/publicdomain/zero/1.0/) applies to the data made available in this article, unless otherwise stated.

\section{Conclusion}

Point-of-care ultrasound may be a useful modality for the quick diagnosis and follow-up of tracheal edema caused by smoke inhalation.

Published: 31 January 2014

doi:10.1186/2036-7902-6-S1-A26

Cite this article as: Kameda and Fujita: Point-of-care ultrasound detection of tracheal edema caused by smoke inhalation. Critical Ultrasound Journal 2014 6(Suppl 1):A26.
Submit your manuscript to a SpringerOpen ${ }^{\circ}$ journal and benefit from:

- Convenient online submission

- Rigorous peer review

- Immediate publication on acceptance

- Open access: articles freely available online

- High visibility within the field

- Retaining the copyright to your article 